\title{
An Accounting Writing Proficiency Survey
}

Tim Firch, California State University, Stanislaus, USA

Annhenrie Campbell, California State University, Stanislaus, USA

Steven Filling, California State University, Stanislaus, USA

David H. Lindsay, California State University, Stanislaus, USA

\begin{abstract}
Although there has been much discussion about improving college student writing with collegelevel courses, little is known about how accounting programs, in particular, are addressing the writing proficiency challenge. This study surveys the 852 accounting programs in the United States to identify the frequency and types of accounting writing courses currently offered. Results indicate that few schools require an accounting-specific writing course or require students to pass any kind of writing proficiency test as juniors or seniors. Most programs do, however, require students to demonstrate English composition skills within several of the upper division accounting courses. Most department chairs do not believe that the graduates of their programs write well enough.
\end{abstract}

Keywords: writing skills course; writing proficiency; accounting education

\section{INTRODUCTION}

haracterized by the Sarbanes-Oxley Act and the newer Dodd-Frank Act, today's financial reporting environment is heavily oriented toward compliance issues. Evaluating and documenting compliance involves text preparation and review rather than computation. At the same time, financial reporting is undergoing rapid evolution that is expected by many to result in the virtual elimination of differences between United States and International GAAP. International GAAP, often characterized as being more "principles based" than U.S. GAAP, may lead to more, rather than less, written documentation and explanation within financial reporting.

Thus, accounting today is hardly just "number crunching." Extensive documentation must be prepared by practitioners to demonstrate compliance with complicated rules and guidelines which are promulgated in written form. Whether these rules and guidelines are available in paper volumes or via computerized databases, students will be expected to research, understand and write in this environment.

This evolution of the skillset needed by entry-level accountants to include expanded writing skills has been implicitly recognized by the AICPA (American Institute of Certified Public Accountants) in a redesign of the CPA (Certified Public Accountant) Exam, which has become more research-oriented and explicitly tests students' written communication skills.

The growing demands for reading, research and writing skills, in addition to computational skills, have led many to recommend approaches to improving accounting students' writing abilities in college programs. The California State University system has addressed the writing proficiency issue on a system-wide basis by requiring each campus to evaluate students' writing skills, both at the lower and upper division levels [CSU, 2009]. The upper division requirement is an attempt to assure that students, upon graduation from a CSU campus, exhibit sufficient writing competence. Campus implementation of the CSU system-wide initiative may be applied at the major or discipline level which has provided an opportunity for an accounting-specific approach to the writing proficiency course at CSU campuses. 
In addition to a brief review of the literature and recommendations for offering a writing proficiency curriculum to accounting students, this study presents the results of direct queries to find out how accounting faculties, including those within the CSU, are currently addressing the writing proficiency issue.

\section{LITERATURE REVIEW}

Not only has good writing long been recognized as a necessary accomplishment of graduating accounting students, good writing is held by many to be a critical element of the learning process itself. Numerous articles encourage accounting educators to improve the writing components of the accounting curriculum and others mourn how little has been accomplished [i.e. Corman, 1986; Northey, 1990; Rothenburg, 2002].

The recognition of a need for additional writing competence by accounting graduates and new hires is not recent. A 1992 study that has been cited to support the need for increased writing in the curriculum documented how little progress had been made to that time. The study's respondents were both academics and practitioners and a difference in priorities between the groups was observed. While both agreed that more writing was necessary in the curriculum, the practitioners believed that the more technical aspects, such as the preparation of research memos and engagement letters, can be learned on the job as long as students have a good, basic general business writing background [Sriram and Coppage, 1992]. The lack of progress was also documented in a 1993 analysis that found coverage of writing in business texts less than what practitioners seemed to want. While calling for additional general business communications class work, the authors of this study recommended more coverage of topics specific to accounting [Maupin and May, 1993].

In introducing a rigorous examination of their university's writing program for accountants, McIsaac and Sepe listed three categories of writing courses for accounting students: general business writing courses, specific accounting communications courses, and integrated approaches combining extensive writing practice with core content instruction [1996]. The third of these approaches recognizes that professional writing in each discipline has unique characteristics and constitutes a "discourse community." Proponents of the idea of discourse communities emphasize that content and concepts are best learned through appropriate written assignments representative of the documents prepared in the discipline. In Australia, the discourse community concept has evolved based on the belief that writing ability is key to students' success in most aspects of life. In this approach, learning accounting content and learning to write about accounting content are interconnected. In the application of the discourse community approach, students are taught to focus on the needs of the reader, however, their work is assessed to evaluate competence with the course content [English et al, 1999].

Detailed implementation guidelines have been developed for this "writing to learn" approach [Catanach and Rhoades, 1997]. The McIsaac and Sepe course implementation was notable for inviting local CPAs to join with students for some of the class sessions. Another university's writing course employed a writing specialist who was also a CPA [McCleary, 1997]. Except for occasional discussions about preferable staffing of such programs, it seems most believe existing accounting faculty would conduct the writing course. The challenges of finding appropriate teachers for the course and understanding what training and background are necessary to teach the course are also discussed.

Perhaps as a measure to avoid hiring specialized faculty and to reduce the burden on existing faculty, several promising incremental approaches to adding writing proficiency to accounting courses have been suggested. Student composition skills can be improved using web-based assistance [Cleaveland and Larkins, 2004]. Very clear guidance regarding specific writing problems is available to faculty attempting to add a writing component to their course [Stout and DeCrema, 2004]. Faculty can learn how to make students aware of their own basic writing mistakes in order to clarify their written accounting communications by stressing basic skill improvement [Ramaglia, 1988]. In fact, the "how-to" literature suggesting ways to provide the writing study course to accounting students is extensive. Additional examples include using the SEC plain English guidelines in the classroom [Catanach and Golen, 1996; Reinstein and Houston, 2004], using problem-based materials [Hansen, 2006], using peer-reviewed procedures [Matherly, 2009], using mini-cases [Chu, 2010] and others. 
In discussing their university's writing course for accountants, O'Connor and Ruchala argue that the general business writing course, while better than a general education approach to writing, is not ideal for accounting majors [1998]. The combination of discipline-area study with writing skills development is often termed "writing across the curriculum" and is used in other major areas of study in addition to accounting. Programs adopting this approach expect improvement both in writing performance and content mastery of accounting students. This approach has been characterized as "theoretically sound" [Garner, 1994; O'Connor and Ruchala, 1998]. Proponents argue that the writing course assists students to order their thoughts and the editing process provides an opportunity for students to exercise their critical thinking skills [Reinstein and Trebby, 1997].

Some studies have attempted to measure what progress results from focused writing courses addressed to accounting students. Two older studies suggest that greater improvement from the writing course can be found among the lower performing students in a cohort [Baird, 1998; Faris et al, 1999]. One explanation of this finding is that students uncomfortable with their writing abilities may choose accounting because they perceive it as computational [Faris et al, 1999]. It can be challenging to adequately measure any improvement of writing skills that may result from a specific course. Assessment of improvement requires good assignments and a detailed grading system that addresses both technical (grammar) skills and professional document quality of student output [Ashbaugh et al, 2002].

Practitioner literature periodically discusses writing skills and often provides practitioners with assistance and pointers. Some articles explain why CPAs should be able to write [Duff and Zidulka, 2008]. Others point out that CPAs really do significant amounts of writing in practice [Chiurri and Varaksina, 2006; Kranacher, 2007]. Most just tell accountants how to improve in various areas specific areas such as preparing tax memos or employing adequate composition for good documentation [Larkins, 2003; Eyres, 2003]. Not all suggestions for practicing accountants are directed to CPAs in public or tax practice. Governmental and management accountants are also encouraged to improve their writing skills on the job [Downing, 1999; Messmer, 2001].

The practitioner literature has addressed the writing skills of recent graduates, the entry-level candidates. An Australian publication provided writing guidelines to professionals, including the new accountant just starting on the job [Walters, 1996]. One article suggested that the interview and hiring process include collecting a writing sample [Porter, 1997].

Surveys of accounting students' writing skills, such as the one presented here, typically address the academic community. Few studies and writing programs consider or include practitioners. While students are taught to keep the users in mind as they write, little empirical work has been done to understand users' responses to this output [Sriram and Coppage, 1992].

\section{HYPOTHESES}

In a previous study, it had been determined that the 23 California State University campuses use a range of different approaches to teach and test writing proficiency [Firch et al, 2010]. Although all CSU campuses respond to a system-wide initiative called the GWAR, Graduate Writing Assessment Requirement, implementations vary. In addition to a diagnostic test called the EPT, or English Placement Test, administered to all incoming freshmen, the GWAR requires evaluation of student writing performance at the upper division level. This evaluation is administered sometime before graduation, usually as an exit requirement after a student has completed any required writing courses. Some campuses require students to pass the GWAR writing proficiency exam before enrolling in the upper division writing course (students not able to pass complete remedial writing courses - not providing graduation credit - and tutoring).

Some of the campuses approach the writing proficiency issue at the college or program level while others do so only as a general education requirement. Depending on the CSU campus, accounting students might study writing skills in a general education course, in a business administration course or within an accounting-specific course. 
Those campuses which evaluate and teach student writing proficiency within the discipline level do so in a number of ways. Some campuses include a writing component within every course in a student's major or concentration while others offer a specific writing course as a major area graduation requirement. Reviewing the various methods in place at the different CSU campuses raised the question whether this wide variation of approaches was more than simply a CSU phenomenon. Using the CSU examples and a review of the relevant literature, we prepared nineteen questions for the questionnaire used in this survey study.

The implicit hypothesis of this study is that colleges and universities outside the CSU are also evaluating and teaching writing proficiency at both the lower and upper division levels and are using a variety of approaches. The resulting questionnaire addresses the impact on accounting students of the various approaches.

\section{METHODOLOGY}

The e-mail addresses of department chairs of 852 accounting programs in the United States were identified using Hasselback's Accounting Faculty Directory 2008-2009. Using the Survey Monkey service, the chair of each program was sent a cover letter with our 19-question survey.

Of the 852 surveys, 78 recipients had previously opted out from any Survey Monkey query and were automatically excluded. Another 52 surveys were returned as "undeliverable" probably due to outdated email addresses. Of the 722 surveys successfully sent to recipients a response was received from 90 yielding a response rate of $12.47 \%$. No tests were run to understand whether early, late and nonresponders were similar. Therefore, we cannot make any assertions that those who responded to our survey were similar to those who did not.

\section{THE QUESTIONS AND ANSWERS}

\section{At your university, do incoming freshmen take a writing proficiency assessment?}

Of the respondents, only about $49 \%$ said yes, freshmen take a writing proficiency test. Other universities may assess their freshmen by relying on information from the SAT writing score or simply use set course requirements for writing and composition for all entering students.

\section{If your freshmen students take a writing proficiency assessment, are low-scoring students required to take non-college credit remedial courses in English composition?}

Of those schools testing incoming freshman, just over two thirds did require that low scoring students take remedial non-college credit coursework. The other third did not. However, since our survey referred to "non-college credit", the schools may have required remediation, but granted credits.

\section{How many lower division English composition courses are required of students in your undergraduate accounting program?}

About $40 \%$ of respondents answered one course and 55\% said two. Three per cent said no courses were required, and the final two per cent said that more than two were required. Although there are only a couple of respondents requiring the three or more English composition classes, such requirements represent a great deal of writing work for what is a historically computationally based major.

\section{Does your university have an upper division writing course requirement? \\ $53 \%$ of respondents said they had such a course.}

\section{If so, is that course housed in the Business College?}

About half of those who have such a course said it was housed within the business college, and thus, presumably tailored to address the needs of business students. 
6. What is the enrollment cap for upper division writing courses?

The enrollment cap on such courses varied, with a maximum of 39 students. About $17 \%$ of respondents said they kept enrollment in such courses under 20, and 57\% said that such upper division courses were capped between 20 and 29, with the remaining respondents allowing caps in the 30s.

7. Does your university require students to pass an upper division writing proficiency exam?

Only about eight per cent of respondents said yes they had such a requirement.

8. If an upper division writing proficiency exam is required, is it required before entry to an upper division writing course?

Of the handful that did have such a required exam, only two in addition to the CSU campus noted above required passage of this exam prior to enrolling in an upper division writing course. Presumably the other schools use the exam as an exit requirement.

9. How many upper division writing courses are students in your undergraduate accounting program required to take?

Just under $40 \%$ of respondents said no such courses were required, while $47 \%$ said one course only. Of the remaining $13 \%$, all but two schools said two courses were required. Those two schools required three or more such courses.

\section{Are undergraduates in your program required to take an accounting-specific writing course?}

A handful of respondents (11\% of those surveyed) said yes. This would seem to signify that while most schools do have a substantial amount of English composition coursework required of their students in order to graduate, it is still only occasionally course-specific in content, at least for accounting majors.

\section{If so, is that course taught out of the Accounting Department?}

Of the $11 \%$ of schools that require an accounting specific writing course, all but two stated that this course was taught out of the accounting department.

12. How many required upper division accounting courses in your program require students to demonstrate English composition skills?

$18 \%$ of respondents said no courses required this,

$16 \%$ said just one course did,

$21 \%$ said two courses,

and $45 \%$ of those surveyed said more than two.

13. In such courses, the writing assignments are: a major part of the course, a minor part of the course, or neither a major or a minor part of the course?

About $38 \%$ of those who said their curriculum contained such courses said that the writing was a major part of them. About $46 \%$ said the writing was a minor part. This suggests that many schools have put initiatives in place to include some writing requirements within the core accounting curriculum, short of a specific accounting writing or research class. 
14. Accounting classes in your program require research based assignments in which of the following: Tax, GAAP/IFRS, Capital Markets, Ethics, Systems, Auditing, Cost

The most commonly included research assignment topic was tax research (81\% responding affirmatively), Remaining courses listed as including research assignments were respectively, Auditing (69\%), and then GAAP/IFRS (66\%). Finally, about a third each said they included some written work in Ethics (35\%), Cost Accounting (32\%), or Systems Research (31\%) in their curriculum.

15. Research assignments in accounting courses either parallel the new CPA Exam research and writing portion, or are intended to prepare students for this CPA Exam portion. Agree or Disagree?

About $30 \%$ each agreed and disagreed, with the other $40 \%$ expressing no strong opinion on this. The three most commonly assigned CPA exam writing topics are tax, auditing and GAAP with IFRS to be added in 2011. It is not clear whether the CPA exam content is a cause or just an association with the three most commonly offered writing research topics as indicated in the previous question. Most schools do not seem to be focusing on teaching to prepare for the CPA exam, but do seem to refer to the exam for guidance in preparing students, in general, for professional accounting duties.

16. Research assignments in accounting classes are used to provide an opportunity to address contemporary issues in accounting education. Agree or Disagree?

Just over $66 \%$ of respondents agreed and only $7 \%$ disagreed with this. This might indicate that the research course is used to cover contemporary issues in accounting education that may not be fully integrated into the regular texts, such as convergence with IFRS, simplification of promulgated guidelines and regulations, and the conceptualization of principles-based standards.

17. Are undergraduates in your program required to take a course in business communications apart from any required writing proficiency courses?

$48 \%$ answered in the affirmative.

18. In your opinion, do graduates of your program write well enough?

Responses to this question suggest a level of candor as only $37 \%$ of respondents said yes. This is of course not a failure, but merely an admission of additional work to do in the future, a goal to be aspired to.

19. Do employers of your students [e.g. Business Advisory Boards] consider your students competent writers?

Here the response was more positive with a 52\% affirmative result. Possibly this means that an academic assessment of a student performance might have higher expectations and thus be less forgiving than that of an employer.

\section{RESULTS AND RECOMMENDATIONS}

An examination of the literature on college writing for accounting majors suggests that how students should be studying writing is somewhat unsettled. Although anecdotal discussion of accountants' writing tasks is widespread, there is little documentation of what specifically students should be prepared to do in practice. Perhaps a practice analysis, such as the one prepared by Siegel and Kulesza detailing actual management accounting tasks in the field, should be prepared to analyze the writing tasks facing graduating accounting students [1996]. Of course, the perceptions of the practitioner community can be gathered by other means. A particular school may choose to address local employers to understand their requirements and level of satisfaction with the writing skills exhibited by that school's graduates. 
Related to the idea of identifying just what writing skills and abilities should be taught to accounting students is the need for better measuring of outcomes. Such assessment takes both an internal and an external aspect. Internal to each program, a method to measure student progress from the start to the end of the writing skills course or courses would be useful to determine the effectiveness of the course and to find which students are benefiting the most.

Many students proceed to graduate level study after completing the undergraduate curriculum, a trend accelerated by the 150-hour requirement in most states for CPA licensing. Another assessment that is internal to the academic environment, if not internal to a specific undergraduate program, is finding out whether students in graduate-level accounting programs bring adequate writing proficiency with them to graduate school.

More difficult would be an external outcomes measure to quantify whether graduates are achieving expectations in practice, after completing their studies. This last issue is briefly addressed toward the end of the questionnaire with questions addressing the performance of students after graduation and the perspectives of their employers. Such issues need to be queried first-hand from the employers themselves rather than just using the observations of academics.

One potential measure of external outcomes would be student performance on the CPA exam. The 2011 iteration of the exam specifications includes a written communications component comprising $15 \%$ of the score of the BEC (Business Environment and Concepts) Section of the exam. It may or may not be possible to compare student performance, school by school, on this section of the exam with the writing curriculum design in place in each school. This may not be a useful outcomes measure due to the conflicting influences of curriculum covering the many different topics included in this section of the exam, such as cost accounting, information systems, economics IFRS (international financial reporting standards), and others.

The questionnaire did confirm that the range of variation in approaches to writing study for accounting students first found in the CSU reflects the national situation. It could be possible that some of the variation in approach is a response to budgetary constraints as some schools find it difficult to add new faculty, let alone new faculty with the special set of skills necessary to teach a technically appropriate, content-based accounting writing course. It can be hoped that future studies can document more widespread and better teaching of writing skills to accounting majors and suggest interesting ways to accomplish this challenging task.

\section{AUTHOR INFORMATION}

Tim Firch, J. D., L. L. M., is an adjunct professor of accounting and business law. A graduate of the University of California, Davis, King Hall School of Law, he is a member of the California State Bar, taxation section (inactive in good standing). His research and teaching interests center on writing skills development for upper division accounting students. His writing skills courses include a major accounting research component. He also teaches business law and financial accounting.

Annhenrie Campbell, Ph.D., CPA, CMA, CGFM is a Professor of Accounting at California State University, Stanislaus. She holds a Ph.D. from the University of Colorado in Boulder. Her research interests include the impact of faculty research on students' professional preparation and academic success. She teaches advanced financial accounting and governmental accounting courses.

David H. Lindsay, Ph.D., CPA (inactive), CISA, CFE is a Professor of Accounting and the Chair of the Department of Accounting and Finance at California State University, Stanislaus. His Ph.D. is from the Graduate School of Management at Kent State University. His research interests include determinants of CPA Exam pass rates, the impact of merit programs on research and teaching outcomes, fraud detection, and various AACSB related issues. He teaches Intermediate Accounting I and II.

Steven Filling, Ph.D., CPA (inactive), is Professor of Accounting at California State University, Stanislaus. His $\mathrm{Ph} . \mathrm{D}$. was awarded by Louisiana State University. His research interests include critical accounting theory, ethics and corporate tax policy. He has been recognized for including community service in his coursework and is active in 
faculty governance and representation. He teaches Information Systems and has developed courses on ethics and writing within the Accounting discipline.

\section{REFERENCES}

1. Ashbaugh, H., K.M. Johnstone and T.D. Warfield, "Outcome Assessment of a Writing-Skill Improvement Initiative: Results and Methodological Implications," Issues in Accounting Education, Volume 17, Number 2, May, 2002, pp. 123-148.

2. Baird, J.E., R. C. Zelin II, and L.A. Ruggle, "Experimental Evidence on the Benefits of Using 'Writing to Learn' Activities in Accounting Course," Issues in Accounting Education, Volume 13, Number 2, May, 1998, pp. 259-276.

3. California State University: Office of Public Affairs, Historic Milestones, retrieved 12/5/09 from http://www.calstate.edu/PA/info/milestones.shtml.

4. Catanach, A. H. and S. C. Rhoades, "A Practical Guide to Collaborative Writing Assignments in Financial Accounting Courses," Issues in Accounting Education, Volume 12, Number, 2 Fall, 1997, pp. 521-536.

5. Cleaveland, M. C., and E. R. Larkins, "Web-Based Practice and Feedback Improve Tax Students' Written Communication Skills," Journal of Accounting Education, Volume 22 , 2004 pp. 211-228.

6. Corman, E.J., "A Writing program for Accounting Courses," Journal of Accounting Education, Volume 4, Number 2, Fall, 1986, p. 85-95.

7. Chiurri, M. and A. Varaksina, "End of the Myth: CPAs Do Have to Write," The CPA Journal, Volume 76, Number 5, May, 2006, p. 10.

8. Cue, L. and T. Libby, "Writing Mini-cases: An Active Learning Assignment," Issues in Accounting Education, Volume 25, Number 2, 2010, pp. 245-265.

9. Downing, M.S., "Turning Numbers in Words," The Government Accountants Journal, Volume 48, Number 1, Spring, 1999. p. 20.

10. Duff, C and A. Zidulka, "Why Writing Skills are Vital for CAs," Beyond Numbers, Number 470, April, 2008, p. 14.

11. English, L., H. Bonanno, T. Khnatko, C. Webb, and J. Jones, "Learning through Writing in a First year Accounting Course," Journal of Accounting Education, Volume 17, Spring-Summer, 1999, pp. 221-254.

12. Eyres, P. S., "Every Word counts: Business Communications that Win in the Courtroom," The National Public Accountant, November, 2003, p. 34.

13. Faris, K.A., S.P. Golen and D.H. Lynch, "Writing Apprehension in Beginning Accounting Majors," Business Communication Quarterly, Volume 62, Number 2, June, 1999, pp. 9-21.

14. Firch, T, A. Campbell, D.H. Lindsay, and D.E. Garner, "On Developing the Writing Skills Course for Accounting Students," American Journal of Business Education, Volume 3, Number 4, April, 2010, pp. 6166.

15. Hansen, J.D., "Using Problem-Based Learning in Accounting," Journal of Education for Business, Volume 81, Number 4, Mar/April, 2006, pp. 221-224.

16. Hasselback. J.R., Prentice-Hall Accounting Faculty Directory 2009-2010, 33/e retrieved 11/6/10 from http://www.jrhasselback.com/ [2009-2010 edition shows faculty listings for 2008-2009 academic year, current directory is posted at http://www.pearsonhighered.com/accounting]

17. Kranacher, M "The Problem with Communication. . . "The CPA Journal, Volume 77, Number 7, July ,2007, p. 80.

18. Larkins, E. R., "Briefing Judicial Decisions in Tax Practice: A Lost Art?" The National Public Accountant, Volume 46, Number 8, October, 2001, page 41-43.

19. Matherly, M. and L. Burney, "Using Peer-Reviewed Writing in the Accounting Curriculum: A Teaching Note," Issues in Accounting Education, Volume 24, Number 3, August, 2009, pp.393-413.

20. Maupin, R. J. and C.A. May, "Communication for Accounting Students," The International Journal of Educational Management, Volume 7, Number 3, 1993, p. 30-38.

21. McCleary, B., "Changes in Accounting Education Include Increased Use of Writing Tasks," Composition Chronicle: Newsletter for Writing Teachers, Volume 10, Number 3, April, 1997, pp. 1-4.

22. McIsaac, C. M and J.F. Sepe, "Improving the Writing of Accounting Students: A Cooperative Venture," Journal of Accounting Education, Volume 14, Number 4, 1996, pp. 515-533. 
23. Messmer M., "Enhancing Your Writing Skills,” Strategic Finance, Volume 82, Number 7, January, 2001, p. 8 .

24. Northey, M., "The Need for Writing Skill in Accounting Firms," Management Communication Quarterly, Volume 3, Number 4, May 1990, pp. 474-495.

25. O'Connor, T.J. and L. V. Ruchala, "A Model for Small-Group Writing Labs in an Accounting Curriculum," Issues in Accounting Education, Volume 13, Number 1, February, 1998, pp. 93-111.

26. Porter, J.A., "Writing Skills of New Accounting Hires: The Message is Mixed," The Tax Adviser, Volume 28, Number 8, August, 1997, p. 518.

27. Ramaglia, J., "Writing (English as a Second Language) in Accounting," Presented at Pacific Lutheran University, April 1988.

28. Reinstein, A. and J. P. Trebby, "How Accounting Educators Can Help Improve Their Students' Writing Skills," Journal of Education for Business, Volume 73, Number 2, Nov/Dec, 1997, pp. 105-113.

29. Rothenburg, E., "How Writing Across the Curriculum can be Incorporated into Accounting Programs," The CPA Journal, Volume 72, Number 4, April, 2002, p. 14.

30. Siegel, G. and C. S. Kulesza, "The Practice Analysis of Management Accounting," Management Accounting, Volume 77, Number 10, April, 1996, p. 20-26.

31. Sriram, R. S. and R. E. Coppage, "A comparison of Educators and CPA Practitioners' views on Communication Training in the Accounting Curriculum," Journal of Applied Business Research, Volume 8, Number 3, 1992, pp. 1-11.

32. Stout D. E., and J. J. DaCrema, "A Writing Intervention for the Accounting Classroom: Dealing with the problem of Faulty Modifiers," Journal of Accounting Education, Volume 22, Number, 2004, pp. 289-323

33. Walters, K., "Have We Made Ourselves Clear?" Australian Accountant, Volume 66, Number 7, August, 1966, p. 40. 
NOTES 